\title{
Perilaku Masyarakat Terhadap Benda Cagar Budaya Sangiran: Studi Kasus Di Desa Krikilan
}

\section{Bambang Soelistyanto}

Keywords: cultural resource management, development, protection, ethnography

\section{How to Cite:}

Soelistyanto, B. Perilaku Masyarakat Terhadap Benda Cagar Budaya Sangiran: Studi Kasus Di Desa Krikilan. Berkala Arkeologi, 15(1), 46-64. https://doi.org/10.30883/jba.v15i1.654

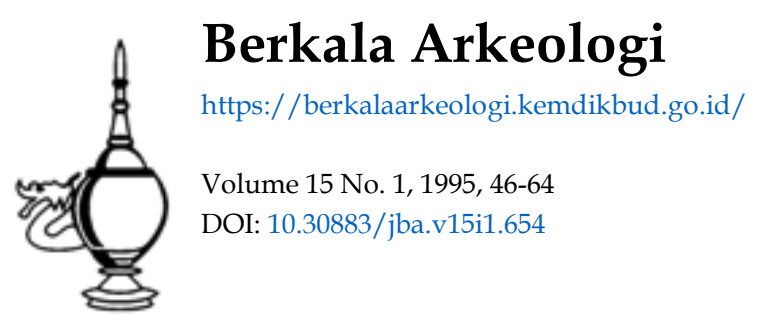

This work is licensed under a Creative Commons Attribution-NonCommercial-ShareAlike 4.0 International License. 


\title{
PERILAKU MASYARAKAT TERHADAP \\ BENDA CAGAR BUDAYA SANGIRAN : \\ Studi Kasus di Desa Krikilan
}

\author{
Bambang Sulistyanto. \\ (Balai Arkeologi Yogyakarta)
}

\section{Pendahuluan}

Situs Sangiran dalam dunia ilmu pengetahuan khususnya dalam masalah evolusi manusia purba penting, hal tersebut tidak diragukan lagi. ' Temuan demi temuan mulai dari rahang bawah (mandibula) kanan hasil temuan Von Koenigsvald pada tahun 1934 hingga tengkorak pithecantrophus temuan Sugimin pada tanggal 8 Oktober 1993, menampilkan bukti, bahwa kubah Sangiran merupakan situs hominid terkemuka di dunia.

Sayang sekali sebagian besar temuan fosil manusia di situs ini, justru bukan berasal dari hasil penelitian para peneliti. Melainkan temuan dari penduduk setempat yang praktis aktivitasnya jauh mempunyai peluang yang lebih banyak dibanding dengan suatu penelitian formal (Anonim, 1993).

Keterlibatan masyarakat setempat dalam pencarian Benda Cagar Budaya (BCB) Sangiran sudah cukup lama berlangsung. Sejak Von Koenigsvald pada tahun 1934-1936 mengadakan eksplorasi di situs ini, penduduk sudah dilibatkan dalam usaha mengumpulkan fosil-fosil. ${ }^{2}$ "Tradisi"

\footnotetext{
- Pernah disajikan dalam Evaluasi Hasil Studi Teknis Pengembangan Cagar Budaya Sangiran, Surakarta, 4-6 Agustus 1994

' Situs Sangiran merupakan situs terlengkap di Indonesia, baik ditinjau secara stratigrafis maupun antropologis.Dari Segi stratigrafis situs ini menyimpan suatu seri stratigrafis yang tidak terputus sejak Pliosen Akhir ( 2.4 juta tahun lalu) hingga Akhir Plestosen Tengah (120.000 tahun lalu), dan didukung dengan temuan lebihkurang 50 individu manusia purba (Homo erectus). Ini berarti temuan Homo erectus di Sangiran telah menempati sekitar 65 persen dari seluruh temuan fosil hominid di Indonesia dan mencakup 50 persen populasi fosil Homo erectus di dunia. Oleh karena itu, situs ini dinilai sebagai salah satu pusat evolusi di dunia, sekaligus sebagai tolok ukur untuk mengkaji proses-proses evolusi manusia secara umum (Anonim, 1993/1994).

2 von Koenigsvald bahkan menerapkan sistem upah atau pemberian hadiah berupa uang bagi penduduk yang berhasil menemukan, baik itu fosil manusia atau
} 
pencarian fosil, khususnya setelah hujan turun, masih terus berlanjut sampai sekarang.

Kesadaran warga setempat terhadap makna penting BCB dirasakan masih minim. Sebab beberapa realitas memperlihatkan adanya unsur kesengajaan (bukan ketidaktahuan) memperlakukan BCB sebagai barang komoditi yang menguntungkan. Kasus Subur - Donald E. Tyler merupakan contoh kecil dari rendahnya sikap dan perilaku masyarakat Sangiran yang berdampak negatif bagi kelestarian situs tersebut. Luas Situs Sangiran minimal $4 \times 8 \mathrm{~km}$ mencakup empat (4) wilayah kecamatan dan dua (2) kabupaten, yaitu Kecamatan Kalijambe, Gemolong, dan Plupuh (Kabupaten Sragen) serta Kecamatan Gondangrejo (Kabupaten Karanganyar).

Dengan berbagai keterbatasan, tidak mungkin tulisan ini membahas perilaku seluruh masyarakat Sangiran yang cukup kompleks tersebut. Pada kesempatan ini, sebagai sampel hanya akan dicoba mengamati perilaku masyarakat Desa Krikilan, Kecamatan Kalijambe, Kabupaten Sragen. Adapun alasan dipilihnya Desa tersebut, karena interaksi antara masyarakat desa setempat dengan BCB terlihat paling menonjol di antara desa-desa lainnya, yaitu sebagai berikut :

1. Sebagian masyarakat desa masih melanjutkan kebiasaan pecarian fosil sejak masa von Koenigsvald pada tahun 1930-an hingga saat ini.

2. Aktivitas sehari-hari beberapa warga Desa Krikilan masih berkaitan erat dengan BCB Sangiran. Hal ini didukung oleh keberadaan beberapa sentra industri kerajinan batu di desa setempat yang menyebabkan semakin intensifnya pemanfaatan fosil untuk barang-barang kerajinan.

3. Museum Sangiran berada di wilayah desa ini secara tidak langsung menjadi pusat aktivitas mereka dalam mendukung perekonomian yang sekaligus melibatkan BCB Sangiran. Keberadaan Museum tersebut juga

hewan. Be-sarnya hadiah itu menurut Toto Marsono (mantan Kades Krikilan, pemandu von Koe-nigsvald waktu itu) tergantung dari jumlah dan jenis fosil serta kelangkaannya. Hadiah itu berkisar antara 2 ketip sampai 5 sen. Tetapi jika penduduk bisa menemukan "untu bledek" (kapak batu) von Koenigsvald berani mengganti uang sebesar Rp. 5,- yang menurut perhitungan Toto Marsono uang sebesar itu senilai dengan harga seekor lembu pada waktu itu (Wawancara dengan Toto Marsono; lihat juga B. Soelist, "Di-lema Padang Purbakala Sangiran", Intisari No, 365 Desember 1993, hal. 12-19). Se-jak itu masyarakat Sangiran khususya warga Desa Krikilan mulai terlatih mencari fosil dan terbentuk suatu pola komersialisasi fosil. 
menjadikan semakin intensifnya interaksi warga setempat dengan masyarakat luar, pengunjung museum.

Bertolak dari realitas di atas ada tiga permasalahan utama yang ingin dijawab dalam tulisan ini: Pertama, mengapa sikap dan perilaku masyarakat Desa Krikilan rendah terhadap BCB? Kedua, faktor-faktor pendukung apa saja yang menyebabkan negatifnya sikap dan perilaku tersebut? Ketiga, Bagaimana penanggulangan terhadap proses pemiskinan BCB itu?. Ketiga pokok permasalahan ini tentu saja tidak akan mampu terjawab secara terperinci, namun beberapa segi penting akan dicoba dikemukakan.

Teknik penjaringan data yang dipergunakan dalam penelitian ini melalui kuesioner yang disebarkan merata di 10 pedukuhan di Desa Krikilan. Pada saat ini penduduk Desa Krikilan berjumlah 3.644 jiwa atau 692 KK. Guna pembahasan ini dipergunakan 70 kepala keluarga sebagai sampel atau 10,1 \% dari jumlah kepala keluarga yang ada. Ditentukannya Kepala Keluarga sebagai sasaran penelitian, hal ini berdasarkan pertimbangan, bahwa kepala keluarga adalah penentu kebijakan dalam pengambilan keputusan dalam rumah tangga.

Guna mempertajam pembahasan dilakukan juga interview langsung terhadap beberapa pamong, pemuka masyarakat, dan berbagai pihak lainnya. Keputusan untuk mempergunakan kuesioner tersebut, tidak dimaksudkan untuk tujuan tertentu, karena maksud dari pengamatan ini adalah hanya sebagai usaha pengumpulan bahan deskriptif yang bersumber langsung dari masyarakat yang bersangkutan, untuk selanjutnya perlu dikembangkan dalam bentuk penelitian situs Sangiran yang lebih luas dan mendalam di masa mendatang.

\section{Kondisi dan Potensi Desa Krikilan.}

\subsection{Kondisi.}

Secara administratif Desa Krikilan berada di Wilayah Kecamatan Kalijambe, Kabupaten Sragen, Jawa Tengah. Desa ini terletak sekitar 4,5 km dari jalan raya Solo - Purwodadi atau $15 \mathrm{Km}$ dari Kabupaten Surakarta. Luas wilayah Desa Krikilan 449,254 ha, meliputi 64, 416 ha tanah sawah dan 384,838 ha tanah kering. Tanah kering tersebut meliputi 93,258 ha tanah pekarangan, 281,362 ha tegalan, sisanya 10,23 ha berupa tanah kisik, yaitu berupa jalan, kuburan, lapangan dII.

Desa Krikilan berada pada ketinggian $125 \mathrm{~m}$ di atas permukaan air laut membujur dari arah utara ke selatan dengan batas-batas: sebelah utara 
dibatasi tegalan Desa Ngebung, sebelah selatan dibatasi sungai Cemoro, sebelah barat tegalan Desa Jetis dan sebelah timur dibatasi tegalan Desa Bukuran.

Seperti halnya desa-desa di kawasan Sangiran lainnya, kondisi tanah pertanian Desa Krikilan tidak begitu subur. Secara geografis letak desa ini lebih tinggi daripada Sungai Cemoro yang terletak di sebelah selatannya, sehingga air sungai ini tidak dapat dimanfaatkan sebagai pengairan sawah. Para petani dalam mengerjakan sawah tergantung dari air hujan, sehingga mereka tidak bisa leluasa dalam memilih jenis tanaman yang akan ditanam. Pada musim penghujan, mereka memanfaatkan tanaman padi. Sedangkan pada musim kemarau, jenis tanaman yang tumbuh adalah jenis palawija.

Meskipun lahan tanah Desa Krikilan kurang mendukung untuk pertanian, namun pada kenyataannya sektor pertanian masih menjadi lapangan kerja yang paling dominan, sebagaimana ditunjukkan tabel 1 di bawah ini. Kurang suburnya tanah untuk pertanian, merupakan salah satu faktor penyebab rendahnya taraf hidup masyarakat.

\section{Tabel 1 Mata Pencarian Penduduk Desa Krikilan Th. 1993 (Berdasarkan} Umur 10 Tahun Ke atas).

\begin{tabular}{||c||c||l||l||}
\hline $\begin{array}{c}\text { Jenis } \\
\text { Pekerjaan }\end{array}$ & $\begin{array}{c}\text { Juml } \\
\text { ah }\end{array}$ & Jenis Pekerjaan & Jumlah \\
\hline \hline Petani & 859 & Brh. Bangunan & 342 \\
Brh tani & 941 & Pedagang & 106 \\
Pengusaha & 77 & Angkutan & 2 \\
Brh industri & 218 & Peg. Negeri & 22 \\
\hline
\end{tabular}

Sumber: Kecamatan Kalijambe dalam Angka Tahun 1993.

Buruh tani dalam arti mereka bukan pemilik tanah, menempati urutan pertama berjumlah 941 orang, urutan kedua petani 859 orang dan urutan ketiga buruh bangunan 342 orang. Pengelompokkan garis besar tersebut dilakukan untuk memperlihatkan mata pencarian yang ditekuni tidak lebih dari separo waktu kerja. Sebab matapencarian ganda terjadi pula di Desa Krikilan. Seperti terjadi di desa-desa lain di Jawa, di mana orang mencari penghasilan dari berbagai sumber pada waktu yang bersamaan atau berganti-ganti pekerjaan seirama dengan munculnya kesempatan kerja yang bersifat musiman (White, 1977:16). 


\subsection{Potensi.}

Tabel 1 di atas secara tidak langsung menunjukkan potensi di bidang perindustrian cukup berperanan dalam penyerapan tenaga kerja (tercatat 218 orang atau $8,5 \%$ dari jumlah keseluruhan usia kerja yang ada). Potensi industri di Desa Krikilan adalah jenis industri kecil dan industri rumah tangga. Salah satu di antaranya adalah industri kerajinan batu. Dalam prakteknya industri tersebut sering memunculkan permasalahan bagi kelestarian situs Sangiran sehubungan dengan bahan yang dipergunakan.

Potensi lain yang terdapat di Desa Krikilan, adalah tersedianya fasilitas pendidikan dan sosial budaya yang sedikit banyak akan berpengaruh pada sikap dan perilaku masyarakat. Dalam bidang pendidikan tersedia 4 buah sekolahan yang meliputi TK dan SD dengari 27 orang guru. Mayoritas warga Krikilan beragama Islam, dengan jumlah masjid 4 buah dan langgar 7 buah. Potensi Pertahanan dan Keamanan tersedia 33 Hansip penjaga ketertiban.

Fasilitas pengangkutan pribadi yang dimiliki oleh penduduk berupa sepeda 194 buah, sepeda motor 21 buah dan truk 1 buah (Mantri Statistik,1993: 66). Akses berupa jalan aspal adalah jalan menuju jalan utama Solo - Purwodadi, dibuat sehubungan fungsi pariwisata budaya (Museum Sangiran) yang dikembangkan oleh pemerintah daerah. Selain itu jalan tersebut membuka kesempatan luas bagi warga desa ini untuk berinteraksi secara intensif dengan masyarakat kota.

Dalam pengamatan lapangan, memperlihatkan gerak sirkulasi harian penduduk desa ke daerah perkotaan cukup tinggi. Setiap hari terdapat puluhan penduduk yang bepergian ke kota Surakarta karena di dorong oleh berbagai tujuan, antara lain; bekerja, sekolah atau belanja. Hal ini menunjukkan bahwa interaksi penduduk desa dengan masyarakat kota cukup tinggi.

Demikian pula sebaliknya, keberadaan Museum Sangiran serta kehadiran industri kerajinan batu, menjadikan warga desa ini semakin luas berinteraksi dengan masyarakat luar. Pengamatan memperlihatkan, seringnya wisatawan asing maupun wisatawan domestik yang secara individual mengunjungi beberapa sentra industri kerajinan batu di sana dengan berbagai ragam tujuan. Sedikit banyak realitas ini akan berpengaruh pada perilaku warga Desa Krikilan terhadap BCB Sangiran. Sebab, 
khususnya turis asing, menurut beberapa informan, tidak sedikit memesan fosil tertentu untuk tujuan yang beragam.

Potensi tersebut di atas menunjukkan, bahwa meskipun letak desa ini relatif jauh dengan perkotaan (15 km dari Surakarta), namun desa ini cukup terbuka terhadap sentuhan pengaruh masyarakat luar. Dilihat dari kondisi masyarakatnya, desa ini masih memiliki ciri kuat sebagai pedesaan. Hal ini terlihat jelas dari mata pencarian penduduk dan jumlah fasilitas umum perkotaan yang tersedia. ${ }^{3}$

\section{Opini dan Perilaku Masyarakat Terhadap BCB}

\subsection{Opini Masyarakat Krikilan.}

Pada hakekatnya pengetahuan masyarakat Desa Krikilan tentang arti penting BCB cukup positif. Hal ini terlihat jelas Di antara responden tidak kurang dari $98 \%$ mengatakan BCB berguna dan perlu dilindungi. Demikian pula pengetahuan mereka mengenai peraturan atau UU BCB, dapat dikatakan cukup positif. Tersurat $85,7 \%$ mereka menyatakan pernah mendengar peraturan Benda-benda purbakala (maksudnya UU RI No. 5 tahun 1992 tentang BCB). Sedangkan sisanya, 14,3\% menjawab belum pernah mendengar.

Persepsi masyarakat terhadap BCB di sekelilingnya dipengaruhi oleh masukan arus informasi yang pernah diterimanya. Dalam konteks informatif inilah dapat diketahui bahwa masyarakat menerima informasi tentang UU BCB dari berbagai macam sumber sebagaimana terlihat dalam tabel 2 di bawah ini.

${ }^{3}$ Untuk mengukur status perkembangan desa, Biro Pusat Statistik menerapkan tiga indikator berikut: (a) angka kepadatan penduduk, (2) Persentase rumahtanga pertanian, dan (3) jumlah fasilitas umum perkotaan. Lihat Hananto Sigit dan Agus Sutanto, "Desa dan Penduduk Perkotaan Menurut Definisi Perkotaan Sensus Penduduk 1971 dan 1980", di dalam Peter F. Mc Donald (Ed.), Pedoman Analisis Data Sensus Indonesia 1971-1980 (Yogyakarta:Gadjah Mada University Press, 1984 hlm.131-136) 


\section{Tabel 2, Sumber Informasi Masyarakat Tentang UU Benda Cagar Budaya.}

\begin{tabular}{||l|c||c||}
\hline \multicolumn{1}{|c|}{ Mengetahui dari } & Jumlah & $\%$ \\
\hline \hline Radio /televisi & 31 & 44,3 \\
Surat kabar & 3 & 4,3 \\
Teman/saudara & 7 & 10,0 \\
Penyuluhan/Penerangan & 19 & 27,1 \\
Belum mendengar & 10 & 14,3 \\
\hline \hline \multicolumn{1}{|c|}{ JUMLAH } & 70 & 100,0 \\
\hline
\end{tabular}

Tabel 2 memperlihatkan sumber informasi mengenai pentingnya BCB, terbanyak berasal dari media elektronik, yakni, 44,32 \%. Hal ini menarik untuk dikaji, mengingat sarana perhubungan yang ada di desa ini relatif minim. Pada tahun 1993 tercatat pemilik televisi sejumlah 74 keluarga atau $11 \%$ dari jumlah seluruh rumah tangga yang ada. Sedangkan jumlah pemilik radio 323 keluarga atau $47 \%$ dari jumlah seluruh rumah tangga di Desa Krikilan (Mantri Statistik,1993:66). Namun mempertimbangkan keeratan hubungan sosial sebagaimana kebanyakan masyarakat marginal lainnya, sebenarnya angka di atas tidak mengherankan. Lebih-lebih belakangan ini, situs Sangiran seringkali ditayangkan di media massa sehubungan dengan peristiwa Subur-Donald E. Tyler.

Angka terendah sumber informasi yang diterima oleh masyarakat Krikilan, adalah sumber berupa media cetak, yaitu 4,3\%. Sebenarnya media cetak, khususnya media cetak daerah di lingkungan D.I.Yogyakarta dan Jawa Tengah sudah cukup mengekspos permasalahan situs Sangiran menurut versinya tersendiri. Namun kondisi demikian ini dapat dipahami, sebab pelanggan media cetak berkaitan dengan profesi dan tingkat pendidikan masyarakat. Untuk memahami isi media cetak, diperlukan kemampuan imajinasi dan atensi yang cukup (focused reader) dan hal ini tidak biasa dilakukan oleh masyarakat yang rendah pendidikannya (Assegaff, 1982:27). Di samping itu, rendahnya taraf hidup masyarakat juga merupakan faktor utama untuk dapat berlangganan media cetak.

Tabel di atas juga memperlihatkan, sumber informasi dari pemerintah (penyuluhan) relatif kurang, yaitu $27,1 \%$. Akibatnya, sejumlah 70 responden yang sempat terjaring 10 di antaranya (14,3\%) menyatakan belum pernah 
mendengar peraturan mengenai benda cagar budaya. Realitas ini cukup menyedihkan, mempertimbangkan intensitas proses pemiskinan situs Sangiran cukup tinggi.

Satu hal yang cukup menggembirakan, masyarakat Desa Krikilan mendukung kebijakan pemerintah dalam hal pemberian imbalan jasa bagi orang yang sadar menyerahkan BCB hasil temuannya. Di antara responden yang terjaring, $98 \%$ menyatakan dukungannya atas pemberian imbalan jasa tersebut, sedangkan $2 \%$ sisanya menjawab tidak. ${ }^{4}$ Hal tersebut diperkuat pada tabel 3 , yaitu $81,4 \%$ beberapa responden menjawab akan menyerahkan ke Museum jika seandainya menemukan fosil di Situs Sangiran.

\section{Tabel 3, Pendapat jika Mereka Menemukan Fosil Situs Sangiran.}

\begin{tabular}{||l||c||c||}
\hline \multicolumn{1}{|c||}{ Jawaban } & Jumlah & $\%$ \\
\hline \hline Menyimpan & 3 & 4,3 \\
Menjual & 6 & 8,6 \\
Memberitahu teman & 4 & 5,7 \\
Menyerahkan ke Museum & 57 & 81,4 \\
\hline \hline \multicolumn{1}{|c|}{ JUMLAH } & 70 & 100 \\
\hline
\end{tabular}

Dari data di atas, dapat dikatakan, bahwa pengetahuan masyarakat Desa Krikilan tentang BCB situs Sangiran sebenarnya cukup positif. Artinya, pengetahuan mereka terhadap makna penting BCB itu sudah ada, merekapun tahu larangan berikut sanksi hukum pelanggaran. Salah satu faktor penyebab realitas tersebut kemungkinan akibat gencarnya arus informasi media massa yang membicarakan Situs Sangiran dengan berbagai permasalahannya. Secara tidak langsung dengan media elektronik tersebut pengetahuan masyarakat bertambah dan akan mempengaruhi pandangan mereka. Tetapi apakah hal tersebut akan berpengaruh pada sikap dan perilaku mereka dalam mengidentifikasikan BCB di lingkungannya?

${ }^{4}$ Pernyataan beberapa responden tersebut sesuai dengan jumlah daftar temuan fosil yang diserahkan oleh penduduk ke Museum Sangiran. Daftar penyerahan fosil ter-catat 73 warga dari berbagai desa di kawasan Sangiran telah menyerahkan hasil temuannya, 21 di antaranya berasal dari penduduk Desa Krikilan (Lihat Daftar Pene-muan Fosil Situs Sangiran 1988 - 1994). 


\subsection{Sikap dan Perilaku Masyarakat Krikilan.}

Mengacu pada rumusan yang diusulkan oleh Berkowitz (1972), yang dimaksudkan dengan sikap di sini adalah suatu respon evaluatif yang memberikan kesimpulan nilai terhadap stimulus dalam bentuk positif atau negatif, baik atau buruk, suka atau tidak suka yang kemudian mengkristal sebagai potensi reaksi terhadap obyek. Dengan demikian, respon sikap yang tercermin dalam bentuk tindakan atau perilaku sebenarnya telah didasari oleh evaluasi dalam diri individu.

Dalam konteks demikian inilah, M. Polak mengatakan, bahwa suatu pendapat seseorang belum tentu sesuai benar dengan sikap dan perilaku yang sesungguhnya.Sebab antara opinion dan attitude adalah berbeda, tetapi dengan menanyakan pendapat, orang dapat meraba sikap (Polak, 1979:96).

Tabel 4 di bawah ini secara tidak langsung menunjukkan sikap dan perilaku Masyarakat Desa Krikilan masih rendah dalam memperlakukan BCB Sangiran. Di antara responden $37 \%$ mencerminkan sikap ketidakpedulian manakala mereka menjumpai berbagai pelanggaran yang terjadi, sedangkan $33 \%$ menunjukkan kepeduliannya. Berkenaan dengan nilai fosil, $60 \%$ di antara mereka berpendapat BCB Sangiran dapat ditukar dengan uang, sedangkan $40 \%$ lainnya menyatakan sikap yang cukup positif.

\section{Tabel 4, Respon terhadap pelanggaran}

\begin{tabular}{||l||c||c||c||c||c||}
\hline \multicolumn{2}{||l||}{ Respon terhadap pelanggaran } & \multicolumn{3}{|c||}{ Fosil dapat ditukar dengan uang } \\
\hline \hline Jawaban & Jumlah & $\%$ & Jawaban & Jumlah & $\%$ \\
\hline \hline Melapor & 33 & 47,1 & Ya & 42 & 60 \\
Diam saja & 37 & 52,9 & Tidak & 28 & 40 \\
\hline \hline JUMLAH & 70 & 100 & - & 70 & 100 \\
\hline
\end{tabular}

Perbandingan antara tabel 3 dengan tabel 4 menarik untuk dikaji lebih lanjut. Sebagai contoh $81,4 \%$ dari responden menyawab akan menyerahkan ke Museum Sangiran seandainya menemukan BCB (fosil), di lain sisi $52,9 \%$ menyatakan sikap apatis jika menjumpai pelanggaran. Konfirmasi dari berbagai pihak diperoleh informasi, bahwa masyarakat Krikilan sebenarnya menyerahkan fosil-fosil temuannya ke Mussum, namun fosil yang diserahkan tersebut sebagian besar hanya berupa fragmen sedangkan fosil yang utuh cenderung untuk di simpan yang pada akhirnya* akan dijual kepada mereka yang memerlukan. 
Salah satu bukti kuat tentang hal tersebut adalah sikap dan perilaku sebagian masyarakat rendah terhadap BCB, terlihat pada kesengajaan mereka mencari fosil setelah hujan turun.' Pencarian fosil itu berakibat semakin meningkatnya pangsa perdagangan fosil secara liar, ${ }^{6}$ sekaligus pemalsuan bentuk BCB. Tetapi apa yang mereka perjualbelikan itu kadangkadang bukan fosil asli melainkan fosil tiruan' yang mendekati bentuk aslinya, sehingga hal ini sering menyulitkan aparat keamanan .

Pengamatan lapangan memperlihatkan, beberapa warga Desa Krikilan mahir dalam bidang pemalsuan bentuk asli fosil. Demikian pula sebaliknya, fragmen-fragmen fosil yang asli seringkali dibentuk dan dirubah sedemikian rupa menjadi barang-barang kerajinan untuk tujuan komersial. Aktivitas pemalsuan fosil tersebut, pada umumnya justru dilakukan di berbagai sentra industri kerajinan. Bahkan menurut beberapa informan, ada indikasi tengkorak-tengkorak manusia dari makam-makam kuno diperbukitan dijarah kemudian dimodifikasi sedemikian rupa menjadi kesan fosil sungguhan.

${ }^{5}$ Beberapa nara sumber yang dihubungi menyatakan, sampai sekarang beberapa war-ga Krikilan masih melakukan tradisi perburuan fosil setelah hujan turun dengan cara menelusuri lereng-lereng bukit atau pematang sawah. Perburuan fosil ini sampai jauh menjangkau di luar kawasan Desa Krikilan. Situs sangiran khususnya pada formasi Pucangan dan Kabuh banyak mengandung fo fosil, tempat tersebut rapuh dan mudah longsor jika terkena air hujan. Hal tersebut menyebabkan fosil bermunculan diakibat-kan oleh adanya erosi atau longsornya tanah segera diambil untuk dijual kepada me-reka yang memerlukan.

6 Pada umumnya para pembeli fosil orang asing yang menyembunyikan identitasnya. Transaksi biasanya terjadi di luar Sangiran, namun ada juga yang langsung menda-tangi rumah salah seorang tengkulak seperti peristiwa pada tahun 1991. Dua turis asal Thailand tertangkap ketika sedang melakukan transaksi dua buah fosil badak (Rhinoceros) di salah sebuah rumah penduduk (Kompas, 23 Oktober 1993).

${ }^{7} \mathrm{Hal}$ ini tergambar jelas dalam insinden di salah sebuah hotel di Surakarta pada tahun 1980, seorang turis tertipu oleh seorang tengkulak yang mahir dalam hal pemalsuan fosil (Zaman 24 Oktober 1982,27-29). Cara kerja para tengkulak dalam mencari pem-beli, menurut seorang informan beragam dan cukup rapi. Setiap turis asing yang da-tang di Krikilan, tidak lepas dari pengamatannya. Masalah harga dan bentuk benda ti-dak diputuskan di Sangiran. Biasanya perantara meminta alamat di mana pembeli bisa dihubungi sambil membawa fosil yang diinginkan. Tetapi fosil dimaksud belum tentu asli, seperti kejadian yang telah diuraikan di atas. 
Perburuan dan sindikasi BCB Sangiran sudah mencapai taraf yang cukup memprihatinkan. Perilaku yang berdampak negatif bagi proses pemiskinan BCB Sangiran ini, selain dilakukan oleh sekelompok orang yang cukup profesional, juga dikerjakan oleh beberapa petani setempat yang telah dihasut oleh mereka yang memanfaatkan. Secara sederhana dapat dilihat pola hubungan sindikat BCB Sangiran pada skema di bawah ini:

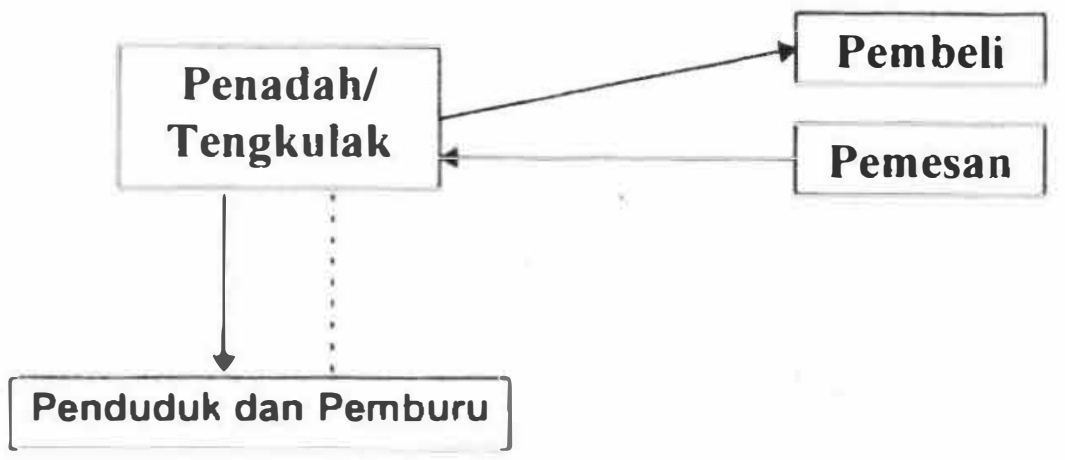

Penadah atau tengkulak adalah pelaku I yang memegang kunci dari keseluruhan proses transaksi BCB termasuk di dalamnya adalah penentuan harga dan pencarian pembeli. Sedangkan penduduk dan "pemburu" adalah pelaku II yang bekerja atas inisiatif pelaku I. Perbedaan penduduk dan "pemburu" terletak pada intensitas keterlibatannya. Keterlibatan penduduk dalam proses pemiskinan BCB hanya bersifat kebetulan pada saat mereka mengerjakan sawah atau aktivitas lainnya. Sedangkan pemburu, secara sengaja mencari fosil untuk tujuan komersialisasi. Hasutan dari pelaku I inilah yang menyebabkan pelaku II (yang sebagian terbesar petani bertaraf hidup rendah) akhirnya cenderung memilih menyerahkan ke pada pelaku II daripada menyerahkan temuannya kepada pemerintah sebagaimana terlihat pada kasus Sugimin.

Kenyataan tersebut yang harus diperhatikan, meskipun pelaku II bertindak atas inisiatif pelaku I, dalam prakteknya pelaku II setelah menemukan fosil merasa memerlukan jasa dari pelaku I untuk mengkomersiilkan BCB temuannya. Di sini barulah pelaku I tersebut mencarikan pembeli atau pemesan yang menurut beberapa informan sebagian besar turis asing.

BCB Sangiran biasanya ditemukan ketika pelaku II sedang mengerjakan sawah atau secara sengaja mencarinya setelah hujan turun. Temuan mereka yang utuh diserahkan ke tengkulak sedangkan temuan fragmen dilaporkan ke Museum Sangiran atau dijadikan bahan untuk pembuatan barang-barang kerajinan. 


\section{Penyebab Rendahnya Sikap Dan Perilaku Masyarakat Krikilan Terha- dap BCB.}

\subsection{Faktor utama}

Sebagaimana telah diketahui, sikap sosial terbentuk karena adanya interaksi sosial yang dialami oleh individu. Interaksi sosial di sini mengandung arti lebih daripada sekedar adanya kontak sosial dan hubungan antar individu sebagai anggota kelompok sosial. Dalam interaksi sosial, terjadi hubungan saling mempengaruhi di antara individu satu dengan yang lain, terjadi hubungan timbal balik yang turut mempengaruhi pola perilaku masing-masing individu sebagai anggota masyarakat. Lebih jauh, interaksi sosial itu meliputi hubungan antara individu dengan lingkungan fisik maupun lingkungan psikologis di sekelilingnya (Azwar,1988:24).

Dalam interaksi sosialnya, individu bereaksi membentuk pola sikap dan perilaku tertentu terhadap berbagai objek psikologis yang dihadapinya. Di antara berbagai faktor penyebab mengapa sikap dan perilaku masyarakat Desa Krikilan rendah terhadap BCB Sangiran, adalah "tradisi".

Sebagaimana diungkapkan oleh Azwar (1988:72) kebudayaan dimana kita hidup dan dibesarkan mempunyai pengaruh besar terhadap pembentukan sikap dan perilaku kita. Sejajar dengan konsep tersebut, dapat dijumpai pula dalam psikologi khususnya yang mempelajari permasalahan sikap, yaitu bahwa perilaku manusia sekarang adalah hasil belajar pada masa sebelumnya (Nimpoeno,1980:26-30), sehingga penyimpangan-penyimpangannya pun adalah hasil belajar (yang kurang relevan) pada masa sebelumnya. Demikian pula yang terjadi pada masyarakat Desa Krikilan, "tradisi" atau kebiasaan berburu fosil yang diperkenalkan oleh von Koenigsvald pada tahun 1934-1936, tanpa disadari telah membentuk sikap dan perilaku mereka terhadap BCB. Apalagi dalam perburuan fosil tersebut von Koenigsvald menerapkan sistem upah sebagai pengganti fosil temuan. Sistem upah semacam ini memancing perhatian bagi masyarakat setempat yang rata-rata memiliki taraf hidup yang rendah. Tetapi secara tidak langsung hal ini telah membentuk sikap dan perilaku masyarakat desa setempat terhadap nilai komersial BCB Sangiran hingga sekarang.

\subsection{Faktor Pendukung.}

Suatu sikap seperti tercermin dalam perilaku masyarakat Desa Krikilan sekarang, tidak mungkin dapat berkembang tanpa adanya faktor 
pendukung. Di antara berbagai faktor pendukung yang mempengaruhi pembentukan sikap tersebut adalah, faktor minimnya informasi, citra buruk pemerintah di mata masyarakat, serta merebaknya industri kerajinan batu.

Minimnya informasi tentang manfaat $B C B$, baik dalam bentuk informasi sehadap (penyuluhan) maupun informasi melalui media, menyebabkan minimnya apresiasi masyarakat terhadap BCB Sangiran. Rendahnyaapresisasi masyarakat berakibat munculnya persepsi tersendiri sesuai dengan kecenderungan orientasinya. Dalam konteks ini adalah orientasi yang dikaitkan dengan tambahan matapencarian hidup.

Buruknya citra pemerintah di mata masyarakat, menjadikan warga Desa Krikilan semakin menipis kepedulian mereka terhadap nilai-nilai penting BCB Sangiran. Buruknya citra pemerintah di mata masyarakat Krikilan ini, salah satunya tercermin pada pemberian ganti rugi. Menurut penuturan beberapa penduduk, dalam proses pemberian ganti rugi terhadap hasil temuan relatif kecil dan memakan waktu yang lama sampai tahunan. $\mathrm{Hal}$ ini tercermin dalam ungkapan kalimat "Museum (Sangiran) sampun dangu taksih gadah utang katah kalian penduduk". Kalimat klise ini dipergunakan oleh kalangan luas, khususnya warga Desa Krikilan untuk menyatakan sikap lebih memilih menyerahkan temuan yang utuh ke pihak tengkulak daripada ke pemerintah.

Citra buruk pemerintah di mata masyarakat Krikilan di atas, berpengaruh besar pada perilaku mereka dalam memperlakukan BCB di lingkungannya. Kondisi tersebut dipacu lagi oleh munculnya beberapa industri kerajinan batu. Keberadaan industri kerajinan batu tersebut, diselenggarakan mulai tahun 1980, di bawah pengawasan Dinas Perindustrian Kabupaten setempat. Dalam prakteknya, melalui pengamatan memperlihatkan seringnya sentra perindustrian ini dimanfaatkan oleh kelompok orang tertentu sebagai wadah atau "kedok" untuk mengeklploitasi BCB Sangiran. Sekarang ini industri kerajinan batu di Desa Krikilan mencapai jumlah 30 unit usaha dengan melibatkan 60 tenaga kerja pokok dengan prodoksi 100.000 buah pertahun (Laporan Tahunan Departemen Perindustrian Kabupaten Sragen, 1993/1994).

Munculnya beberapa sentra perindustrian kerajinan batu tersebut, membuka cakrawala baru bagi sekelompok masyarakat Krikilan untuk melegalkan BCB. Hal tersebut disebabkan seringnya muncul berbagai pelanggaran transaksi perdagangan fosil asli dan atau fosil palsu seperti 
terjadi pada awal bulan Juli 1994 lalu. ${ }^{8}$ Perilaku semacam ini semakin terpacu seiring dengan kondisi keamanan situs Sangiran yang kurang memadai serta rendahnya taraf hidup masyarakat.

\section{Strategi Perubahan Sikap dan Perilaku.}

Berpegang pada anggapan dasar sebagaimana telah dijelaskan di atas, perilaku negatif masyarakat Krikilan merupakan hasil belajar dari pengalaman masa lampau, maka langkah yang perlu segera dilakukan adalah mengubah dan meluruskan kembali rangkaian sebab-sebab pembentuk perilaku tersebut melalui intervensi berbagai pihak. Intervensi terhadap pola tingkah laku di atas dapat bersasaran:

1. Penstrukturan kembali pola kepribadian dan dengan demikian juga perubahan sikap dan perilaku.

2. Pengkoordinasian kembali pihakpihak yang berkepentingan dalam rangka pembenahan terhadap beberapa faktor pendukung penyebab terbentuknya perilaku sebagaimana dijelaskan di atas.

Bagaimanakah sikap dan perilaku dapat berubah atau diubah? Dalam hal ini teori Kelman sebagaimana diuraikan oleh Secord \& Backman (1964) menyatakan, ada tiga proses sosial yang dapat mempengaruhi perubahan sikap, yaitu: kesediaan (compliance), identifikasi (identification) dan internalisasi (internalization). Dalam konteks demikian ini Azwar (1978:42-44) menekankan pentingnya memperhatikan beberapa faktor eksternal, dari luar individu, yang dinilai berpengaruh dalam mengarahkan sikap dan perilaku kepada bentuk yang dikehendaki. Faktor eksternal yang dimaksud adalah kekuatan komunikator dalam mempengaruhi sikap, efektivitas komunikasi dan strategi pengubahan sikap.

Berdasarkan uraian di atas, maka komunikasi merupakan kunci perubahan sikap dan perilaku masyarakat. Masyarakat Desa Krikilan yang sebagian besar petani yang berpendidikan rendah, maka komunikasi sehadap (penyuluhan) yang persuasif menjadi faktor penting yang perlu diintensifkan. Keberhasilan suatu komunikasi yang bertujuan untuk mengadakan

${ }^{8}$ Dua orang asing sedang melakukan transaksi sebuah fosil. Tetapi dihadapan aparat keamanan, fosil tersebut menurut pemiliknya dikatakan palsu, buatan sendiri. Peristiwa seperti ini sering menghambat proses penanganan disamping membingungkan aparat keamanan. 
perubahan sikap, antara lain tergantung pada kredibilitas komunikator, daya tarik dan kekuatan komunikator itu sendiri.

Pentingnya teknik komunikasi sehadap, Middlebrook (1974:23) mengatakan, teknik komunikasi yang efektif adalah dengan mengemukakan kesimpulan komunikasi secara eksplisit kepada subyek yang sikap dan perilakunya akan diubah dan dengan mengulang-ulang argumentasi yang mendukung sikap yang dituju.

Mempertimbangkan kompleksnya warga Krikilan yang terlibat dalam proses pemiskinan $\mathrm{BCB}$, maka komunikasi sehadap dirasa penting untuk dilakukan per desa atau jika perlu per RW, bukan per kecamatan seperti yang terjadi selama ini. Mempertimbangkan pula tingkat "kenekadan" masyarakat Desa Krikilan dalam proses pcmiskinan BCB, maka perlu mempergunakan komunikator yang memiliki kekuasaan atau power yang dapat membangkitkan rasa segan atau takut untuk menentang sugesti sikap yang ditiupkan.

Dalam proses pengubahan sikap, karena yang dituju adalah masyarakat banyak, maka proses pengubahan sikap dan perilaku tersebut sudah tentu memerlukan saluran-saluran komunikasi lain sesuai dengan kondisi masyarakat setempat. Media cetak dan elektronik, dalam hal ini dapat dimanfaatkan, disamping melalui saluran lain seperti kesenian, sekolahan, dan LKMD, yang tersedia dalam masyarakat bersangkutan.

Pesan komonikator baik secara persuasif ataupun indoktrinasi, tidaklah cukup dengan menyodorkan fakta, melainkan harus diikuti dengan perimbangan dan percontohan yang nyata dari pihak pengubah sikap tersebut. Dalam hal ini penegakan hukum, kecepatan penanganan temuan, maupun proses ganti rugi temuan sebagaimana telah disinggung di atas perlu diefektifkan.

Sebenarnya proses perubahan sikap dan perilaku tidak dapat ditinjau dari satu atau dua faktor secara terpisah, sebab beberapa faktor pendukung pembentukan sikap itu sediri melibatkan berbagai hal yang saling berinteraksi. Oleh karena itu, keterpaduan pengelolaan BCB dengan berbagai pihak terkait perlu ditingkatkan, guna membentuk citra positif di mata masyarakat. Dilain pihak, koordinasi - intergrasi - sinkronisasi dengan kebijakan pembangunan daerah pantas menjadi perhatian utama, khususnya dalam hubungan ini adalah koordinasi dengan pihak perindustrian sehubungan dengan gencarnya perilaku eksploitasi fosil yang diolah dan diperdagangkan. Koordinasi terhadap berbagai pihak bidang 
perindustrian ini, khususnya penekanan pada segi permasalahan bahan yang dipergunakan.

Secara psikologis, perubahan sikap pada mulanya pasti akan menimbulkan gejolak dalam masyarakat penerima. Lebih-lebih perubahan sikap dan perilaku masyarakat Krikilan yang menyangkut obyek fosil sebagai sumber matapencarian mereka. Pembangunan pada masyarakat yang ekonominya terbelakang, diperlukan stimulus sedemikian rupa sehingga dapat memperbesar keberanian mereka untuk mengubah caracara lama (Koentjaraningrat, 1992:30). Oleh karena itu pelurusan kembali terhadap sikap dan perilaku mereka, seyogyanya dicarikan alternatif pengganti mata pencarian lain. Setidaknya, dapat disediakan suatu sistem perangsang yang dapat menarik perhatian masyarakat.

Sistem perangsang itu dapat berupa hak-hak kemudahan seperti keringanan pajak (Kusumohartono,1993:6) atau kemudahan pengurusan KTP bagi mereka yang secara sadar memberikan bantuan terhadap pelestarian BCB Sangiran. Akhirnya, yang perlu disampaikan adalah pelestarian BCB penting didekati melalui studi sosial masyarakat, khususnya terhadap situs-situs rawan yang memiliki dampak kuat seperti Trowulan dan Banten. Konsep pengamatan terhadap perilaku sosial masyarakat Krikilan seperti ini, perlu dikembangkan ke dalam bentuk penelitian yang lebih luas dan mendalam dalam rangka memahami berbagai permasalahan yang muncul di kawasan situs yang rawan ancaman tersebut.

\section{KEPUSTAKAAN}

Anonim. 1992. Kabupaten Daerah Tingkat II Sragen Dalam Angka Kantor Statistik BAPPEDA, Kabupaten Sragen.

Anonim.tt. Daftar Penemuan Fosil Situs Sangiran 1988-1994 Arsip laporan pada Museum Sangiran.

Anonim.1982. Pencurian Fosil Di Sangiran. Zaman, 24 Oktober, hlm. 27-29.

Agus \& B.Sulistyanto.1993.Laporan Hasil Peninjauan Stratigrafi Temuan Fosil Pithecanthropus, Dusun Grogolan Desa Manyarejo, 
Kecamatan Plupuh Kabupaten Sragen Yogyakarta:Balai Arkeologi Yogyakarta.

Assegaff,H.Djafar.1982. Hubungan Media dalam Kegiatan Humas Dalam kumpulan tulisan Hubungan Masyarakat dalam Praktek Jakarta:Ghalia Indonesia.

Azwar, Saifuddin.1988. Sikap Manusia Teori dan Pengukurannya. Yogyakarta, Liberty

Berkowitz,L,1972.Social Psycologi Glenview III Scott, Foresmen and Company.

Harry Widianto,1993/94.Laporan Hasil Penelitian Arkeologi Penelitian Manusia Purba dan Lingkungannya di Situs Sangiran (13-27 Desember 1993), Yogyakarta:Balai Arkeologi Yogyakarta.

Kusumohartono,Bugie.1993.Penelitian Arkeologi Dengan Subkajian Tentang Pelestarian Sumberdaya Arkeologi, Lokakarya Intern Tentang Penelitian, Amdal dan Pelestarian Sumberdaya Arkeologi Balai Arkeologi Yogyakarta. Yogyakarta 10-11 Maret 1993.

Koentjaraningrat (editor).1992.Ciri-ciri Dari Kehidupan Masyarakat Pedesaan di Indonesia dalam Sajogjo \& Pudjiwati Sajogjo. Sosiologi Pedesaan I, Yogyakarta, Gadjah Mada University Press.

Laporan Tahunan Departemen Perindustrian Kabupaten Sragen, $1993 / 4$.

Mantri Statistik. Kecamatan Kalijambe Dalam Angka Tahun 1993

Nimpoeno,S.John.1981.Fungsi Warisan Sebagai Pembentuk Sikap Terhadap Pembangunan. Dalam Anilis Kebudayaan Jakarta:Departemen Pendidikan dan Kebudayaan

Peter,F.1984.Pedoman Analisis Data Sensus Indonesia 1971-1980 Yogyakarta: Gadjah Mada University Press. 
Polak Mayor, 1979.Sosiologi Suatu Pengantar Ringkas. Jakarta: Ichtiar Baru.

Samwega,M Ardus.1993. Sindikasi di Sekitar Sangiran. Kompas 23 Oktober.

Soelist,B.1993.Dilema Padang Purbakala Sangiran. Intisari No.395 Desember 1993, hal. 12-19.

White,B.1977. The Changing Structure of Agricultural and Non Agricultural Employment Opportunities Rural Java". Makalah untuk seminar tentang industri pedesaan, Universitas Gajah Mada Yogyakarta. 
